\title{
Anticipation as a biological phenomenon
}

\section{S. Peric ${ }^{1 *}$}

1. Neurology Clinic, Clinical Center of Serbia, School of Medicine, University of Belgrade

Anticipation means the increased severity and earlier age at onset of a particular disease, or the increased risk for that disease, with every new generation (1).

\section{History}

In 1911 British pathologist F. Mott published his observations that symptoms of serious mental diseases worsened through generations of the same family, until family members were no longer able to reproduce (2). Mott announced that his "law of anticipation"is a method by which nature kills off the poor types and ends biological degeneration. This concept of anticipation was closely linked to the eugenics concept of degeneracy in society.

American eugenicist $C$. Davenport advocated legalization of sterilizing the families with Huntington's disease without their permission (3). In USA and Sweden, mentally retarded people were sterilized until the Second World War (3). Some of the very first families that were legally sterilized and euthanized in Nazi Germany were also the families with Huntington's disease that is a disorder associated with anticipation (3).
The anticipation phenomenon in myotonic dystrophy was described for the first time by Swiss ophthalmologist, B. Fleischer in 1918 (4). He noted that many people affected with muscle wasting had parents only with cataracts that appeared between the ages of fifty to seventy, and grandparents with cataracts in older age. After the Second World War, J. Bell statistically confirmed anticipation in myotonic dystrophy (5). She found that the age at onset of disease was significantly younger in offspring than in their parents. It was obvious that the disease was worsening through the generations of one family.

However, leading British geneticist of the time, L. Penrose, was against the concept of eugenics and against everything he thought was eugenic, including anticipation. He gave an explanation that anticipation is a consequence of the ascertainment bias and not a biological phenomenon (6).

According to Penrose (6), it is easy to see anticipation pairs in clinical practice. When a clinician looks at a child with severe form of a disease, he/she is able to find moderate

\section{Corresponding author:}

S. Peric

Neurology Clinic, Clinical Center of Serbia, School of Medicine, University of Belgrade

Address: 6, Dr Subotica Street E-mail: stojanperic@gmail.com Phone: +3816422287779 Fax: +381 112684577

Receive date: 2014-04-01| Accept date: 2014-04-29 | Publish date: 2014-05-08

DOI: 10.7575/aiac.abcmed.15.03.01.04

\section{A I}


symptoms in a parent, and mild symptoms in a grandparent. However, it is more complicated to see so called complementary pairs, although they are as frequent as anticipation pairs. For example, if you see a grandfather with a severe form, then there is a father with a moderate form and a child with a mild form. This child will have his first symptoms for example sixty years later. It means that at the moment of examination, doctors are able to see anticipation pairs and not complementary pairs. Furthermore, someone with a mild form can have children with a severe form, while somebody with a severe form of the disease will not have children at all. Penrose listed even more biases proving that anticipation is not a biological phenomenon. After this, anticipation has been rarely mentioned in the medical literature.

In 1980s, C. Howeler, a Dutch neurologist, was studying 264 relatives from 14 families with myotonic dystrophy (7). He examined this cohort excluding each of the biases put forward by Penrose and he disproved them statistically. He clearly found that ages of onset diminished through the generation in $98 \%$ of 61 parentchild pairs. Throughout those years, N. Wexler had investigated large pedigrees of Huntington's disease in Venezuela (3). She was able to see children, parents, grandparents, great-grandparents, and great-greatgrandparents at the same time, because people there tend to have children at younger ages. Thus, she was able to notice anticipation in Huntington's disease when transmitted by males.

After this, clinicians and geneticists started to discuss about anticipation again. However, there was no good explanation how anticipation could occur. This phenomenon was against Mendelian genetics that considers mutations invariable. It was not known how certain mutations can lead to worse and worse symptoms and an earlier onset from one generation to the next.

\section{Biological explanation}

For resolving the puzzle of the genetic basis of anticipation, research of the fragile $X$ syndrome was of outstanding importance. Fragile $X$ syndrome is the most common singlegene cause of intellectual disability (8). Since it is an X-linked inherited disorder, it is expected that every male who carries mutation has fragile $X$ phenotype. However, after investigation of fragile $X$ families, it was evidenced that some males who obviously carry the mutation do not develop the symptoms of the disease (so called normal transmitting males) and that proportion of affected males, i.e. chance of expressing the disease, increases in successive generations (9). This is so called Sherman's paradox and it was resolved in 1990s when light was shed on genetic cause of fragile $X$.

In 1991, few research groups isolated a region of DNA consisting of cytosine-guanineguanine (CGG) repeats which showed increase in length through generations of fragile $X$ families (3). Fragile $X$ is a null mutation disease. Approximately, 200 CGG repeats are needed to cause methylation of the gene and block protein synthesis which subsequently leads to the fragile $X$ phenotype. This dynamic mutation was a biological explanation of the pretty bizarre clinical observation - anticipation.

It is of mention that fragile $X$ was not the first repeats disease that was discovered. Few months before fragile $X$, Kennedy's disease (spinal and bulbar muscular atrophy) had been found to have a trinucleotide repeats in the gene of androgen receptor (10). However, this finding had no significant influence on further researches since, in Kennedy's disease, there was no obvious anticipation or obvious increase in expansion. 


\section{Repeat expansion disorders}

Anticipation in fragile $X$ is not typical. It is basically a mental retardation syndrome, and the symptoms are present or absent from birth - they do not get more severe and they do not occur earlier such as in myotonic dystrophy. However, main researchers in the fields of myotonic dystrophy and Huntington's disease recognized anticipation in fragile $X$. They hypothesized that these two diseases may have similar genetic basis as fragile $X$.

This hypothesis was confirmed in 1992 when increased number of CTG repeats was found to cause myotonic dystrophy (11), while in 1993 increased number of CAG repeats was announced to be associated with Huntington's disease (12). There are now up to 30 diseases that have this kind of mutation (Table 1). Majority of them are neurological, probably because the brain tissue is particularly vulnerable since it does not divide, and all the detritus of these large expansions is accumulated.

\section{Fate of expansion}

Because of anticipation, actual dynamic mutation within one family vanishes after three, four or maximum five generations (7). Thus, it seems that these diseases will disappear. However, this is far from the truth since there are sources of new cases of repeat expansion disorders in general population.

All of the present day fragile $X$ mutations are the consequence of a change that occurred in certain number of ancestors 2000 years ago (3). It is a quite recurrent mutation. Changes are occurring continuously. It means that mutations developing at this moment may also lead to the fragile $X$ syndrome in maybe 2000 years from now on.
On the other hand, virtually everyone with

\begin{tabular}{|c|c|}
\hline Disease & $\begin{array}{l}\text { Repeat } \\
\text { expansion }\end{array}$ \\
\hline Fragile $X$ & CGG \\
\hline $\begin{array}{l}\text { Fragile X-associated } \\
\text { tremor/ataxia syndrome }\end{array}$ & CGG \\
\hline $\begin{array}{l}\text { Fragile X-related primary } \\
\text { ovarian insufficiency }\end{array}$ & CGG \\
\hline Fragile XE mental retardation & $\mathrm{CCG}$ \\
\hline $\begin{array}{l}\text { Spinal and bulbar muscular } \\
\text { atrophy (Kennedy) }\end{array}$ & CAG \\
\hline Amyotrophic lateral sclerosis & GGGGCC \\
\hline Frontotemporal dementia & GGGGCC \\
\hline Huntington's disease & CAG \\
\hline Huntington's disease - like 2 & CTG \\
\hline Spinocerebellar ataxia type 1 & CAG \\
\hline Spinocerebellar ataxia type 2 & CAG \\
\hline $\begin{array}{l}\text { Spinocerebellar ataxia type } 3 \\
\text { (Machado-Joseph) }\end{array}$ & CAG \\
\hline Spinocerebellar ataxia type 6 & CAG \\
\hline Spinocerebellar ataxia type 7 & CAG \\
\hline Spinocerebellar ataxia type 8 & CTG \\
\hline Spinocerebellar ataxia type 10 & ATTCT \\
\hline Spinocerebellar ataxia type 12 & CAG \\
\hline Spinocerebellar ataxia type 17 & CAG \\
\hline Friedreich's ataxia & GAA \\
\hline $\begin{array}{l}\text { Dentatorubral-pallidoluysian } \\
\text { atrophy }\end{array}$ & CAG \\
\hline Myotonic dystrophy type 1 & CTG \\
\hline Myotonic dystrophy type 2 & CCTG \\
\hline $\begin{array}{l}\text { Oculopharyngeal muscular } \\
\text { dystrophy }\end{array}$ & GCG \\
\hline
\end{tabular}

Table 1: Repeat expansion diseases

myotonic dystrophy type 1 on this planet have diseases inherited from a common single ancestor that lived 120000 to 60000 years ago. This mutation spread throughout the human population. Probably $1-10 \%$ of people carry a permutation allele (3). They are completely healthy since they have a very small, but unstable mutation.

\section{Conflict of interest statement}

The author have no conflict of interest to declare. 


\section{References}

1. Rieger et al. Glossary of Genetics: Classical and Molecular, 5th ed.

2. Mott F. The inborn factors of nervous and mental disease. Brain 1911;1:73-101.

3. Donachie J, Monckton D. Tomorrow belongs to me. University of Glasgow 2006, 1st ed.

4. Fleischer B. Uber myotonische Dystrophie mit Katarakt. Arch Klin Ophthalmol 1918;96:91-133.

5. Bell J. Dystrophia myotonica and allied diseases. In: Penrose. L. Treasury of Human Inheritance. Cambridge University Press 1947, 1st ed.

6. Penrose L. The problem of anticipation in pedigrees of dystrophia myotonica. Annal of Eugenics 1948;14:125-32.

7. Howeler C, Busch H, Geraedts J, Neirmeijer M, Staal A. Anticipation in myotonic dystrophy: fact or fiction? Brain 1989;112:779-97.

8. Hagerman R, Hagerman P. Fragile X syndrome, diagnosis treatment and research. Johns Hopkins University Press, Baltimore 2002. 3rd ed.

9. Sherman S, Jacobs P, Morton N, Froster-Iskenius U, Howard-Peebles P, Nielsen K, Partington N, Sutherland G, Turner $\mathrm{G}$, Watson $\mathrm{M}$. Further segregation analysis of the fragile $\mathrm{X}$ syndrome with special reference to transmitting males. Hum Genet 1985;69:3289-99.

10. La Spada A, Wilson E, Lubahn D, Harding A, Fischbeck K. Androgen receptor gene mutations in X-linked spinal and bulbar muscular atrophy. Nature 1991;352:77-9.

11. Brook JD, McCurrach ME, Harley HG, Buckler AJ, Church D, Aburatani H, Hunter K, Stanton VP, Thirion JP, Hudson T, Sohn R, Zemelman B, Snell RG, Rundle SA, Crow S, Davies J, Shelbourne P, Buxton J, Jones C, Juvonen V, Johnson K, Harper PS, Shaw DJ, Housman DE. Molecular basis of myotonic dystrophy: expansion of a trinucleotide (CTG) repeat at the 3' end of a transcript encoding a protein kinase family member. Cell 1992;68:799-808.

12. The Huntington Disease Collaborative Research Group. A novel gene containing a trinucleotide repeat that is expanded and unstable on Huntington's disease chromosomes. Cell 1993;72:971-83.

13. Ashizawa T, Epstein HF. Ethnic distribution of myotonic dystrophy gene. Lancet 1991;338(8767):642-3. 